\begin{tabular}{|c|}
\hline Journal of Political Science \\
(A Peer-Reviewed, Open Access International Journal) \\
ISSN 2362-1273 (Print); ISSN 2773-8132 (Online) \\
Volume 21, February 2021, pp. 39-49 \\
https//: www.ejournal of pncampus.edu.np/journals/ips/ \\
\hline
\end{tabular}

\title{
Neighborhood Interest and Security Concerns in Nepal: A Geopolitical Perspective
}

\author{
Bhim Nath Baral \\ Department of Political Science \\ Prithvi Narayan Campus, Pokhara
}

Corresponding Author: Bhim Nath Baral, Email: bhim.baral@prnc.tu.edu.np

DOI: https://doi.org/10.3126/jps.v21i0.35262

Received 12 December 2020, Reviewed 19 December 2020, Published 1 February 2021

\begin{abstract}
Pedestaled on both descriptive and analytical data acquired from secondary sources, this article analyzes the interests of China and India, Nepal's immediate neighbors. Their interest is examined from security point of view against the backdrop of increased Sino-Indian dynamics of competition in Nepal, using a geopolitical perspective. Security is the vital concept in the study of global politics. The world political dynamics is changing rapidly and security dimensions are also changing with it. Both China and India are trying to be the superpowers in the world. So, it is natural for them to influence regional and world politics in accordance of their own interest. In the present time, both of them are contesting to strengthen their position in Nepal due to their strategic position in the regional politics of South Asia. Nepal cannot remain isolated from the interest of immediate neighbors. Nepal's geographical proximity to Tibetan Autonomous Region of China and the issue of Tibetan refugee heightened China's security concerns in Nepal. India, on the other hand, has also remained highly concerned with the increasing Chinese engagement in Nepal as India and Nepal share a long and open border contingent with the 1950 Treaty of Peace and Friendship. In this context of trilateral quandary, it is necessary to balance the China-India paradox because both are equally important for Nepal's security, peace and development.
\end{abstract}

Keywords: Buffer zone, geo-strategic, regional politics, security issues, soft belly

\section{Introduction}

The concept of security is the most crucial aspect in the study of international relations. It has always been an important issue for every individual, society and nation as well. It is needed for all human beings to live and grow and the state requires for survival and development. The concept of security of a nation goes back to the dawn of nation-states themselves. Armies for domestic peace keeping and maintaining national sovereignty have Journal of Political Science, Vol. 21, February 2021 


\section{Neighborhood Interest and Security Concerns in Nepal}

existed since the dawn of recorded history. Civil and national police have also existed for long back. Intelligence agencies and secret services of governments date back to antiquity. While the general concept of keeping a nation secure is not new, the specific modern English term 'national security' came into the common use in the twentieth century.

According to a prominent security scholar, Arnold Wolfers, "Security in an objective sense, measures the absence of threats to acquire values, in a subjective sense, the absence of fear that such value will be attacked" (Quoted, Balzacq \& Cavelty, 2018, p. 1). Primarily speaking, security is the state of being free from danger or injury. It is also interpreted as a guarantee that an obligation will be met. It is also interpreted as the state of being certain that adverse effects will not be caused by some agents under the defined condition. Security is about the identification of threats, to a particular referent object, and the formulation of policy responses to those threats (Mutimer, 2018, p. 56). Survival, safety and stability are concerned with security governance and seem equally applicable to the individual, society, nature and technical system. This concept involves a wide range of actors, rules and practices. It operates in a context where in power is dispersed and sources of authority are hotly disputed (Balzacq \& Cavelty, 2018, p. 6).

The topic has been differently defined by various social scientists, security scholars and ordinary people in their own way. There are many interpretations of the concept of security and each carries a separate explanation to different actors and conditions. Though the concept has its origin as old as human civilization, it still lacks a universal definition. Mostly, the present worldview focuses on the empirical side dealing with contemporary security problems and issues that analyze the foreign and military policies of state (Wagle, 2010, p. 220). It is also found that the concept is viewed through the military centric approach from the eyes of a state. However, the trend of analyzing the concept has been changed after the disintegration of Soviet Union in the early 1990s. This period witnessed the significant decrease of inter-state war and contributed in reduction of traditional security threats (Bhattarai, 2010, p. 28). Its interpretation is made beyond the traditional definition of protection of state.

Protection of sovereignty, territorial integrity and political independence are the fundamental security concerns of every state. It was in rigid form in the traditional state system and is equally important even for a modern world order. Even in the recent past, the concept of security was narrowly defined. With the span of time, its meaning touched new height and got widened. The modern concept of security is no more state centric. The concept is added with several new dimensions. The conventional state centric dimension is now added with human-centric dimension (Mantoo, 2016, p. 68). Human beings now are facing with a large number of non-traditional threats like poverty, illiteracy, malnutrition, child labor, drug trafficking, environmental degradation, civil war and so on.

China and India are emerging twenty-first century world powers. As a rising power in the world politics, China evolves its economic, political, cultural, social and other influences, which are automatically connected with Nepal. On the other hand, India feels its hegemony with South Asian nations concerning security, politics and culture. So, being situated in critical geo-strategic location, Nepal is a matter of concern in relation to China and India regarding their security matters.

Geographically, Nepal is a landlocked country centrally located in the southern part of Asia. The country is bordered in the east, south and west by India and in the north by China. It 


\section{Neighborhood Interest and Security Concerns in Nepal}

shares nearly 1880 k. m. boarder with India and 1414 k. m. with China. Despite its sovereign and independent identity, Nepal has experienced multiple influences from China and India. Nepal's long run political instability and independent identity is conditioned by external factors especially the vested interest of immediate neighbors. In this regard, the questions automatically arise: What are the fundamental security interests of China and India in Nepal? And to what extent their interest is concerned with Nepal? This paper aims to find the answers to these research questions from the geopolitical perspective.

\section{Objectives and methodology}

Exploring the major security interest of China and India is the fundamental objective of this article. The article also aims to analyze their critical security issues concerned with Nepal. China and India have their own geographical position and deepening security interests. Nepal's location between two emerging world powers has greater implications. By considering this fact, some intellectuals and other efforts are also made towards this. The article views these literatures descriptively and analytically from the geopolitical approach. The required data is obtained from the print as well as online secondary sources like books, journals, official documents, newspapers and previous research works as well. The data is qualitative in nature.

\section{Theoretical Framework}

The concept of security is the crucial aspect in the study of inter-state relation. In international relations, each relevant theory pertaining to security has its own interpretations. Since the relation between China, India and Nepal seems paradoxical, history tells that the relation between them is characterized by all friendship, animosities, partnership, rivalry and cooperative nature (Baral, 2019, p. 5). In this context, the mainstream international relations theories: Realism, Liberalism and Constructivism can be applied in the study of security between Nepal, China and India. In addition, the geopolitical perspective is considered as one of the most important approaches to study this issue of security.

Political realism remained the most dominant theory in the past century and is still relevant in the study of security. It is a school of thought that explains international relations in terms of power (Goldstein \& Pevehouse 2008, p. 43). The classical realists believe in the concept that as long as the state is secure, everything within it will be secured. It is based on pessimistic view of human nature. According to this theory, humans are self- interested and egoistic. Groupism, anarchism, egoism and power politics are the major propositions of political realism (Donnelly, 2008, pp. 150-182). The relations are conflictual and may always lead to war and relation is influenced by the value of national security and state survival (Jackson \& Sorensen 2013, p. 312). This theory further focuses that individual is primarily a selfish and power seeking. Individuals are organized in states, each of which acts in a unitary ovary in pursuit of its own national interest (Mingst 2004, p. 66). In the same manner, the two emerging powers i.e. China and India are found active in increasing their dominance in the Asian continent. The already fought war in 1962 along with border and other several issues are not solved yet. Both the countries have equal interest in Nepal mainly for security concerns as Nepal has long and open border with them. 


\section{Neighborhood Interest and Security Concerns in Nepal}

The liberal school of thought believes great potential for human progress in the modern civil society and the capitalist economy. On the contrary to realists, the liberals are more optimistic about the progress of peace and see the rules of international relations as slowly, incrementally evolving through time and potentially becoming more and more peaceful (Goldstein \& Pevehouse 2008, p. 84). From this point of view, China and India are two emerging markets in a more and more interdependent world where trade and commerce shared possibilities towards global governance institution aspire them to work to build foundation of peaceful co-existence. According to liberalists, peace is a normal, almost routine and ritualistic state of affairs whereas war is unnatural and manmade. This school believes that democracy will devote less to military budgets and is more likely to win wars. They claim that the world has seemingly progressed in terms of reducing level of violent conflict. Open economies, trade and interdependence has also contributed to this decline of violence (Walker \& Rousseau, 2018, p. 29). It is also seen that both of them are trying to be global players, which is impossible without compromising with other powers in the matters related to their interests.

Social constructivism, a newly emerged theory, introduced by Nicholas Onuf and developed by Alexander Wendt, is equally applicable in the analysis of security interest. According to this theory, the international system is constituted by idea not by material forces. It argues that the internal make-up of states affects their international behavior (Jackson \& Sorensen, 2013, p. 229). Both, China and India have strong faith in the principle of Panchasheel, nonalignment, values of world peace, principles of international law and United Nation's charter. Security is determined by several economic, historical, social, cultural, religious and geographical dimensions. Neighbours are bound by the value of mutual respect, coexistence and sensitivity to each other's national sovereignty, territorial integrity, concerns and interests and for the fulfillment of the aspirations of their common people for happiness. The value of international organizations and mutual trust expressed through different forums brings the countries in confidence in relation to the protection of interests including security.

Nepal, a tiny landlocked state of South Asia, shares a long open border with China and India. Inspite of long historical tie, the relation between China, India and Nepal is paradoxical. Rivarly between China and India is very old. They had fought war in 1962 and the relation is still cold as they have many unsolved issues. Nepal also has several cases of debate with them. They have serious interest in Nepal mainly in security matter as explained by realists. Likewise, Nepal's direct approach with immediate neighbors provides an easy access for trade and business along with the movement of people. According to liberalists, China and India are two emerging markets. They are in a move toward interdependency through trade and commerce, tourism, shared possibilities towards global governance and building of foundation of peaceful co-existence. It is hard to be victorious in the race of being global power without having warm relation with each other along with a maintained relation with Nepal. Further, China, India and Nepal, all have strong faith in the principle of Panchasheel, values of world peace, international law and charter of United Nations. Social, cultural, economic, religious, ethnic and other dimensions are deeply rooted in their relations. These social elements as explained by constructivists, make their interest more sensitive.

\section{Chinese interest in Nepal}




\section{Neighborhood Interest and Security Concerns in Nepal}

History witnessed that the Nepal-China relation is as old as human civilization on earth. This relation was maintained through Tibet, the autonomous region of China. Geographical proximity, economic, social, cultural and several other dimensions have determined the relation between the two neighbors. Such tie of relation has gained a significant momentum after the establishment of diplomatic relation on 1 August 1955. Prior to this, China was a distant entity and we knew very little of the Chinese people and society. It was Tibet that we were interacting with through the Himalayas.

The Chinese engagement with the outside world aggressively exposed mainly after the Liberation Movement of 1949 and its serious interest grew in Nepal after the annexation of Tibet to China in 1950. The increasing interest of China vividly spelled out by Mao Zedong in his Five Finger Policy. China has pointed out Nepal, Bhutan, Sikkim, Laddakh and Arunanchal Province of India as the major areas of security concerns (Basnyat, 2073, p. 164). The five fingers were essentially mean to serve as a 'new buffer' zone between India and China after the 'old buffer' (Tibet) came under China's sovereign control (Kochhar \& Awasthi, 2016). Despite several differences in size, population, development and power capability, China gives more importance to Nepal for security concerns. Nepal's geostrategic location has made rising China more serious in its security. This matter is mainly related with separationism, terrorism and fundamentalism. The Taiwan case, Free Tibet Movement and East Turkistan Movement for freedom in the Xinjing region are the main security threats for China.

The Tibet issue, Indo-Nepal bilateral relation and Chinese investment in strategically important infrastructure projects are the three major strategic interests of China in Nepal (Singh, 2016, p. 112). The Tibet issue has been one of the major issues in Nepal's affairs with China. It is considered as China's 'soft belly' (Acharya, 2019, p. 211). The situation is very volatile and the first strategic interest starts from here. Nearly 20,000 Tibetan refugees are residing in different parts of Nepal. China is still suspicious that the Tibetan refugees in Nepal conduct anti-China activity under the spiritual, cultural and humanitarian guise, which creates a problem in the relation (Baral, 2019). Despite Nepal's commitment on 'One China' policy, there are many people in Nepal who have spiritual faith on Dalai Lama. Officially, every government in Kathmandu has adhered to the 'One China' policy. But repeated reaffirmations by Nepal do not seem to have assuaged China. The frequency with which China expresses the concerns on this matter and the fact that Nepal feels the need to continually reiterate its adherence demonstrates the elusiveness of stability on this vital front (Upadhya, 2018, p. 171). So, China takes the matter seriously as Nepali soil can be used for anti-China activity by Tibetan refugees.

China is equally interested in control of Indian traditional influence in Nepal and does not feel comfortable in turning Nepal's land as playground by external powers. It has a bitter experience of Khampa insurgency backed by Central Intelligence Agency (CIA) of United States during 1960. Still today China is cautious that to encircle China, anti-China factors are trying to make Nepal as a hub for their task. Besides these, China always held a deep suspicion towards India's role in instigating the Free Tibet Movement in Nepal.

China's investment in strategically important infrastructure projects like airports and highways, railways, roads, and hydropower is equally important from security point of view. Nepal and China have also reached a broad understanding of working together under the framework of Trans-Himalayan Multi-dimensional Connectivity Network (ABC Media Group, 2019, p. 318). China is also expanding its soft power measures to make a deep 


\section{Neighborhood Interest and Security Concerns in Nepal}

outreach in Nepal which include people-people contacts, scholarship and economic aid to run various development projects. In order to secure Tibet, the major portion of Chinese assistance goes to the security sector of Nepal as it does not want any anti-Chinese activities taking place in Nepal that will affect its security (Jaiswal, 2016b, p. 96). It was in 15 May 2017, Nepal officially became the part of Belt and Road Initiatives (BRI) (mega project introduced by China in 2013), which opened the entry of China to South Asia. Besides these, there are regular bilateral talks and cooperation at higher security level in various issues of crime, trafficking, smuggling, terrorism and other matters of challenges.

\section{Indian interest in Nepal}

There are very few countries who share a natural relation like Nepal and India. The relation has been growing ever since the existence of the two countries. However, the relation between Nepal and British India was determined by the Sugauli Treaty signed after AngloNepal War in 1816. Still, the real history of relation between Delhi and Kathmandu began after maintaining diplomatic relation on August 1947 (Muni,2016a, p. 282) and after signing on Treaty of Peace and Friendship in 1950.

Nepal and India share about $1880 \mathrm{~km}$. open border (it is about $1930 \mathrm{k} . \mathrm{m}$. after the publication of new map including Lipulekh, Limpiyadhura and Kalapani on 20 May 2020 by the Government of Nepal), which creates several security challenges between these two historical allies. It is not relevant to raise the question in close relation between two countries, but there are some security issues between the countries that sometimes create challenges. The question of security of India emerged after the independence of India. Division of Hindustan into India and Pakistan and subsequent unrest in the region created a serious security challenge upon newly independent India. Nepal, the northern neighbor, remained one of the critical concerns on the security matter. Jawaharlal Nehru's speech in Indian parliament on 27 November 1959 is sufficient to understand Indian security interest in Nepal. The speech reads, “... any aggression against Bhutan and Nepal would be regarded as an aggression against India...” (Dahal, 2018, p. 55). Further, India’s concern on security matter is visible on Nehru's statement at the background of Communist revolution in China in 1949. It states,

Our interest in the internal condition of Nepal has become still more acute and personal because of the development across our borders, to be frank especially those in China and Tibet. Besides our sympathetic interests in Nepal, we were also interested in the security of our country. From time immemorial the Himalayas have provided us with a magnificent frontier. Ofcourse, they are no longer as impassable as they used to be, but are still fairly effective. We cannot allow that barrier to be penetrated because it is the principal barrier to India. Therefore, much we appreciate the independence of Nepal, we cannot allow anything to go wrong in Nepal or permit that barrier to be crossed or weakened because that would also be risk to our security. (Muni, 2016a, pp. 10-11)

This fact speaks that India is concerned about the expansion of Chinese influence into South Asia, which has been historically India's sphere of influence. The recent Chinese engagement in Nepal adds fuel to this growing 'perceived threat' that China might some day cross this frontier. 


\section{Neighborhood Interest and Security Concerns in Nepal}

India is worried with the expanding its network between various terrorist outfits and Pakistan's Inter Service Intelligence (ISI). From time to time, India has raised its concern to her Nepali counterparts among other bilateral issues. The arrest of deadly Lashkar terrorist, Abdul Karim Tunda, an accused of 26/11 attacks on Mumbai from Banwasa, the western border of Nepal, was the proof of the concern (Khan, 2016, p. 170). Likewise, hijacking of an Indian plane from Kathmandu and grounded in Kandhar of Afghanistan in 1999 made India suspicious about the use of Nepali land against India.

The flow of fake Indian currency is the next vital security concern of India in Nepal. India considers that due to the weak security formation and operation system of Nepal, anti-Indian elements like Pakistani terrorists are enjoying in Nepal. It was found that India's most wanted terrorist, Dawood Ibrahimis operating a Fake Indian Currency Note (FICN) with active help from ISI (Khan, 2016, p. 171). Further, the border dispute with China and the recent Chinese engagement in Nepal is the matter of doubt for India. Pointing out these factors, India has been pledging to Nepal government and political leaders to make treaties about keeping Indian Air Marshal Forces in airport of Nepal and extradition of anti-Indian criminal and terrorists to India. Considering poor security arrangement, India sent its 70 commandos during president Pranab Mukharjee's visit to Nepal in 2016. Moreover, NepalIndia open border is a constant source of security challenge, which is often misused for unwanted activities like smuggling, human trafficking, increment in terrorist activities, drug abuse, illegal border trade and other criminal activities (Pyakurel, 2018, pp. 154-188).

Besides these, a growing Chinese influence in Nepal becomes the threat to India. In the words of Shyam Saran, Indian diplomat, India is worried on Chinese activities in building a number of highways from Tibetan side into Nepal, all the way down to the East-West highway that traverses Nepal, hacking through high mountains and difficult terrain. He also adds that the Tibet highway extended from Lhasa to Shinghatse and could well be extended to Kathmandu across the border in the next few years. He also accepts about Indian weakness for missing to catch the opportunity to take Nepal in side where China has seized the opportunity to walk in (Saran, 2017, p. 171).

\section{India-China rivalry and its impact in Nepal}

The history of Nepal is very close with the history of immediate neighbours. India and China are not only joined with Nepal through land but also are connected with the history from the beginning of civilization. Nepal's relation with them may grew up and fell down due to political change in the respective country, but the relation at people's level still remains unaffected (Verma, 2073, p. 171). In spite of several economic, political, cultural, religious and cultural attachment, India and China have legitimate security concerns and different threat perceptions about each other's intentions in Nepal.

The Sino-Indian rivalry can be traced back to the era of the Cold War. In the post-colonial period, India was attempting to establish itself as a leader in Asia by taking a strong initiative role in the Non-aligned Movement. India, being a close Soviet ally, was viewed with caution by the newly established People's Republic of China. The Tibetan uprising of 1959 and subsequent departure of Dalai Lama solidified the conflict of interest between China and India. The contention between two giants of Asia further exacerbated due to border dispute in Arunanchal Pradesh and Aksai Chin (Chand, 2016). 


\section{Neighborhood Interest and Security Concerns in Nepal}

Prior to 1950, Tibet was an autonomous region which was free from China's control. As British power extended beyond the Himalayas, Tibet played the role of buffer. With China's occupation on Tibet, Tibet ceased to serve the role of a buffer. The extension of Chinese frontier to Nepal has made Nepal a buffer state between China and India (Jaiswal, 2016a, p. 20). It was under Nehru's leadership India had endeavored to maintain the spirit of Panchasheel, which had been inscribed into Sino-Indian relations by the 1954 agreement in Tibet. But this spirit, the feeling that Indians and Chinese were brothers (Hindi Chini Bhai Bhai) disappeared overnight with the Chinese invasion (Kodikara, 1987, p. 42). China and India fought the war in 1962 and still are in debate in several issues. Border issue is yet not solved and tension often arises in matters of trade, investment and other global issues. Being situated in a favorable geographical position Nepal experiences direct impacts from their conflicts. Nepal is well aware of the growing competition between China and India for its influences in Nepal. Nepal has also understood its own strategic importance which was acknowledged way back in the eighteenth century as the King Prithvi Narayan Shah called Nepal as a 'delicate yam between two boulders'(Hamal, 2014). However, Nepal has been remaining neutral in the conflict between India and China. Related to Doklam issue, in June 2017, Nepal had made it clear that it will stay neutral in the latest India-China standoff of Ladakh incident of 15 June 2020, and it wants this issue to be resolved peacefully. Nepal had also remained neutral in Indo-China war of 1962. However, the issue of balanced relation always remained a subject of debate. The formulation of foreign policy on the party line has created more fundamental issues. The leftist government is often blamed for following 'pro-Chinese policy' whereas the rightist or centrist government follows a 'proIndia policy'. But it is the geo-political reality for any government of Nepal not be either 'pro-Chinese' or 'pro-Indian' (Dahal, 2009, p. 35). So, equi-proximity should be maintained in dealing with our immediate neighbours. Highlighting the impacts of Sino-Indian conflict on Nepal, S. D. Muni writes,

On the strategic side of Nepal, India and China triangular relationship, there is a very interesting phenomenon that if the two ends of a triangle come closer then they both become more distance to, and impinge adversely on, the third one. If China and Nepal get closer, India is uncomfortable. If India and Nepal get closer, China would be uncomfortable and if China and India get closer, Nepal should be uncomfortable for losing its strategic space. (Muni, 2016b, p. 8)

\section{Conclusion}

Nepal occupies an extremely favorable location between China and India, the emerging powerhouse of the world. They have their own geographical position and deepening security interest in Nepal. Being small in capabilities, size and land-locked feature, Nepal has very few roles to play at global and regional level. However, its strategic position carries vital importance regarding the security interest of immediate neighbors. It is mainly since the last two decades China and India are expressing their deep interest in Nepal. During the transition from monarchial rule to republican era in Nepal, China lost its permanent, reliable and strong political institution and India completely changed its 'two pillars theory' of 'constitutional monarchy' and 'multiparty democracy'. 


\section{Neighborhood Interest and Security Concerns in Nepal}

The competitive and cooperative relation between China and India has a direct impact on Nepal. China is in race to be global power and is very serious in Tibet matter in relation to Nepal. China is interested in making sure that Tibetan refugees do not create any nuisance from the Nepali territory. India, on the other hand, is worried with long open border and increasing Chinese influence in Nepal. India is not satisfied with the deterioration of its historical legacy in Nepal.

The China-India influence cannot be wiped-out from the foreign policy of Nepal, but what is needed to be done is to balance the China-India conundrum because both are equally important as far as the peaceful Nepal is concerned. It is evident that developing friendly relations with both neighbors is an integral part of our commitment to non-aligned movement and geopolitical reality. Nepal should be committed to prohibit any activities on its land that may pose threat to the security concerns of neighbors or should Nepal tolerate any such activities threatening our independence and security. Nepal should clearly prioritize its national interest and adopt policies in managing its relationship with China and India that best preserve and promote our national interest. A sturdily sovereign Nepal can exercise and follow independent foreign policy to maintain a balance between both India and China.

\section{References}

ABC Media Group. (2019). Prosperity: The foundation year-2018/19. Centre for Asian Policy Research and Studies Media Support Nepal.

Acharya, M. R. (2019). Nepal world view. Vol. I. Adroit Publisher.

Balzacq, T. \& Cavelty M. D. (2018). Theoretical approaches to security. In M. D. Cavelty \& T. Balzacq (Eds) Routledge Handbook of Security Studies (sec. ed.). 1-9. Routledge Taylor \& Francis Group.

Baral, B. N. (2019). Nepal- China- India: Prospects and challenges of trilateralism. Journal of Political Science. 21,1-20.

Baral, B. N. (2018), Changing dynamics of Nepalese foreign policy: Patterns and trends. Journal of Political Science, XVIII, 25-45.

Basnyat, P. S. (2073 B.S.). Nepal-Chin baadbibaad ra sambaad. Mohan Singh Khadka.

Bhattarai, R. (2010). Broadening Nepal's security agenda: Armed conflict, migration and environmental perspectives. In R. Bhattarai and G. S. Wagle (Eds.) Emerging Security Challenges of Nepal. 21-64. Nepal Institute for Policy Studies.

Chand, B. (2016). The yam between two boulders: Analyzing the impact of Sino-Indian power dynamics. In P. Jaiswal \& G. Kochhar (Ed.) Nepal's Foreign Policy and Her Neighbors. 94-111. G.B. Books Publishers.

Dahal, R. K. (2009). Challenges in the formulation of foreign policy for Nepal. In S. R. Pandey \& P. Adhikari (Eds.) Nepalese foreign policy at the crossroads. 19-50. Sangam Institute. 


\section{Neighborhood Interest and Security Concerns in Nepal}

Dahal, S. H. (2018). China-Nepal-India triangle: The dark side of Indo-Nepal relations. Sangri La Books.

Donnelly, J. (2008). The ethics of realism. The oxford handbook of international relations. In Christian Reus-Smit \& Duncan Snidal (Ed). Oxford University Press. 150-162.

Goldstein, J. S. \& Jon C. P. (2009). International relations (Eight Edition). Pearson Dorling Kindersley India Pvt. Ltd.

Hamal, Y. B. (2014). Ecology of Nepal's foreign policy. Nepal Centre for Development and Policy Studies Pvt. Ltd.

Jackson, R. and Sorensen, G. (2013). Introduction to intentional relations: theories and approaches (Fifth edition), Oxford University Press.

Jaiswal, P. (2016a). Nepal's foreign policy and strategic significance. In P. Jaiswal and G. Kochhar(Ed). Nepal's Foreign Policy and Her Neighbours. 1-32. G.B. Books Publishers \& Distributors.

Jaiswal, P. (2016b). Nepal between India and China: demystifying big powers interplay. In P. Jaiswal \& G. Kochhar (Eds). India-China-Nepal-Decoding Trilateralism. 81-106. G. B. Books Publishers \& Distributors.

Khan, A. (2016). Indo-Nepal relations and the China factor. In P. Jaiswal \& G. Kochhar (Eds) India-China-Nepal: Decoding Trilateralism. 163-174. G.B. Books Publishers.

Kochhar, G. \& Awasthi, S. (2016). Race of elephant and dragon in Nepal. Foreign policy of Nepal and her neighbors. 141-155. In P. Jaiswal and G. Kochher (Eds) G. B. Books Publishers.

Kodikara, S. U. (1987). Role of extra regional powers and south asian security. In S. K. Khatri (Ed.) Regional Security in South Asia. 41-55.Centre for Nepal and Asia Studies.

Mantoo, S. (2016). Internal and external security challenges of Nepal. In P. Jaiswal and G. Kochhar(Eds.) Foreign Policy of Nepal and Her Neighbors. 67-93.G. B. Books Publishers.

Mingst, K. A. (2004). Essentials of international relations (Third edition). W.W. Norton \& Company.

Muni, S. D. (2016a). Foreign Policy of Nepal. Adroit Publishers.

Muni, S. D. (2016b). Trilateral engagement between India- China and Nepal. In Pramod Jaiswal and Geeta Kochhar (Ed.) India-China-Nepal: Decoding Trilateralism. 1-10. G. B. Books Publishers.

Mutimer, D. (2018). Critical security studies. In M. D. Cavelty \& T. Balzacq (Eds.).

Routledge Handbook of Security Studies (sec. ed.). 54-63. Routledge Taylor \& Francis Group. 


\section{Neighborhood Interest and Security Concerns in Nepal}

Pyakurel, U. P. (2018). Alternating existing "open border" and consequences: A discussion. In L. R. Baral (Ed). Politics of Geopolitics: Continuity And Change in India- Nepal Relation. (154-182). Adarsh Books.

Saran, S. (2017). How India sees the world: Kautilya to the 21st century. Juggernaut Books.

Singh, B. (2016). Changing dynamics of strategic relationship between China and Nepal: theorizing India's concern. In P. Jaiswal \& G. Kochhar (Eds.). India-China-Nepal: Decoding Trilateralism. 107-118. G. B. Books publishers.

Srivastav, V. K. (2016). Nepal's foreign policy in quest of identity. In Pramod Jaiswal and Geeta Kochher (Ed). Foreign policy of Nepal and Her Neighbors. 33-48. G. B. Books Publishers.

Upadhya, S. (2018). Nepal and the geostrategic rivalry between China and India. Routledge Taylor \& Francis Group.

Verma, A. (2073). Nepal Bharat Sambhandha Janastar ka kehi Apekshya. In B. K. Poudel (Ed.). Nepal Bharat Sambhandha: Bigat, Bartaman ra havishya. 156-172. Milestone Prakashan Tatha Prasharan Ltd.

Wagle, G. S. (2010). New challenges for national security in the changed context. Emerging security challenges of Nepal. In R. Bhattarai \& G.S. Wagle (Eds). 219-272. Nepal Institute for Policy Studies.

Walker, C.T. \& Rousseau, D. L. (2018). Liberalism: A theoretical and empirical assessment. In M. D. Cavelty \& T. Balzacq (Eds). Routledge Handbook of Security Studies. 22-31. Routledge Taylor \& Francis Group. 